\title{
The Effect of Uncoupling Agents on Carbon Dioxide Fixation by a Thiobacillus
}

\author{
By D. P. KELLY* AND P. J. SYRETT \\ Department of Botany, University College London, England
}

(Received 9 August 1963)

\begin{abstract}
SUMMARY
A newly isolated strain (c) of Thiobacillus thioparus is described. The organism oxidizes thiosulphate, sulphide, tetrathionate or trithionate to sulphate; carbon dioxide fixation is coupled to the oxidation of each of these compounds. Concentrations of arsenate, 2,4-dinitrophenol, and other inhibitors of oxidative phosphorylation, inhibit carbon dioxide fixation without appreciably affecting oxygen uptake. Carbon dioxide fixation coupled to sulphide oxidation is more sensitive to arsenate and 2,4-dinitrophenol inhibition than that coupled to thiosulphate oxidation. This result is consistent with the suggestion that thiosulphate oxidation is linked to a substrate phosphorylation which is relatively insensitive to inhibition by 2,4-dinitrophenol and arsenate.
\end{abstract}

\section{INTRODUCTION}

Thiobacilli can grow autotrophically, obtaining energy from the oxidation of inorganic sulphur compounds, while carbon dioxide is fixed by the reactions of the Calvin cycle and by the carboxylation of phospho-enolpyruvate (Aubert, Milhaud $\&$ Millet, 1957; Suzuki \& Werkman, 1958). Carbon dioxide fixation and subsequent biosynthetic processes require ATP and reduced nicotinamide adenine dinucleotide (Trudinger, 1956), which must be generated during sulphur compound oxidation. When thiosulphate is oxidized, NAD is reduced by extracts of Thiobacillus thioparus (Vishniac \& Trudinger, 1962), and ATP is formed by whole $T$. denitrificans organisms (Milhaud, Aubert \& Millet, 1957). ATP is probably formed at several stages in the oxidation of a substrate such as thiosulphate, and both substratelevel and electron transport phosphorylations may take place. Possibly thiosulphate and sulphide are oxidized through polythionate intermediates with oxidative phosphorylations coupled to the flow of electrons to the oxidant (Vishniac, 1952; Trudinger, 1959; Jones \& Happold, 1961). Experiments of Peck (1960, 1962) indicate that at least part of the ATP formed during thiosulphate oxidation arises from substrate-level phosphorylation. In cell-free extracts of $T$. thioparus Peck demonstrated enzymes which (a) reductively split thiosulphate to sulphide and sulphite; $(b)$ oxidized sulphite in the presence of adenosine monophosphate to form adenosine-5'-phosphosulphate (APS); $(c)$ exchanged the sulphate of APS for phosphate to yield adenosine diphosphate and sulphate. ATP can be formed from ADP by adenylic kinase present in the extracts. This substrate phosphorylation is unaffected by 2,4-dinitrophenol, which uncouples oxidative phosphorylations (Peck \&

* Present address: Department of Microbiology, Queen Elizabeth College, London, W. 8. 
Fisher, 1962). We have briefly reported the effect of 2,4-dinitrophenol on $\mathrm{CO}_{2}$ fixation by a newly isolated strain of $\boldsymbol{T}$. thioparus and have suggested that both oxidative phosphorylations and the substrate phosphorylation studied by Peck may be coupled to thiosulphate oxidation by this organism (Kelly \& Syrett, 1963). In the present paper these observations are extended and the effect of other uncoupling agents on $\mathrm{CO}_{2}$-fixation described.

\section{METHODS}

The organism. A strain of Thiobacillus was isolated from canal water by enrichment culture in the medium for Thiobacillus thioparus described by Vishniac \& Santer (1957). A pure culture was obtained by subculture of single colonies from medium solidified with $2 \%$ agar (Difco). Pure cultures were maintained on slopes of $1 \%$ thiosulphate medium, incubated at $30^{\circ}$, and subcultured every other day. The organism was a highly motile Gram-negative rod, about $2-3 \mu \times 0.5 \mu$ in size. Minute clear colonies were formed on agar; these developed an orange centre and deposited sulphur when allowed to age. The organism had a high cytochrome content, with absorption bands at 522 and $551 \mathrm{~m} \mu$. Washed organisms oxidized thiosulphate, tetrathionate, trithionate, sulphide and (very slowly) sulphur; sulphate was the end product. Nitrate or ammonium ion could be used for growth, which was the more rapid with ammonium as nitrogen source. The organism did not grow anaerobically with nitrate as oxidant, nor grow on thiocyanate. It did not grow on a wide range of heterotrophic nutrient media. The organism is regarded as a strain of $T$. thioparus (Vishniac \& Santer, 1957), and is known as strain c.

When cultivated at $30^{\circ}$ in liquid medium containing $1 \%(\mathrm{w} / \mathrm{v}) \mathrm{Na}_{2} \mathrm{~S}_{2} \mathrm{O}_{3} .5 \mathrm{H}_{2} \mathrm{O}$ and flushed vigorously with air, growth was exponential with a generation time of about $2 \mathrm{hr}$ (Fig. 1). No elementary sulphur was deposited during logarithmic growth; growth ceased when thiosulphate was exhausted. Small quantities of trithionate and tetrathionate sometimes accumulated during growth (see Jones \& Happold, 1961).

Growth of cultures. Cultures were grown in medium of initial $\mathrm{pH} 6 \cdot 7-7 \cdot 0$, but the growth rate was unchanged as the $\mathrm{pH}$ value decreased to about 6 as a result of acid production. Growth ceased in unneutralized cultures when they approached pH 3. A final culture volume of $1 \mathrm{l}$. was made by adding $200 \mathrm{ml}$. inoculum to $800 \mathrm{ml}$. sterile medium. The inoculum was grown in the medium of Vishniac \& Santer (1957), containing only $0 \cdot 2 \%(\mathrm{w} / \mathrm{v}) \mathrm{Na}_{2} \mathrm{~S}_{2} \mathrm{O}_{3} .5 \mathrm{H}_{2} \mathrm{O}$, and shaken at $30^{\circ}$ for $14-16 \mathrm{hr}$ after inoculation from a $48 \mathrm{hr}$ slope, and was added, aseptically, to $800 \mathrm{ml}$. of Pyrex glass-distilled water containing $10 \mathrm{~g} . \mathrm{Na}_{2} \mathrm{~S}_{2} \mathrm{O}_{3} .5 \mathrm{H}_{2} \mathrm{O} ; 0.8 \mathrm{~g} . \mathrm{MgSO}_{4} \cdot 7 \mathrm{H}_{2} \mathrm{O} ; 0 \cdot 4 \mathrm{~g}$. $\mathrm{NH}_{4} \mathrm{Cl} ; 3 \cdot 2$ g. $\mathrm{K}_{2} \mathrm{HPO}_{4} ; 3 \cdot 2$ g. $\mathrm{KH}_{2} \mathrm{PO}_{4} ; 8 \cdot 0 \mathrm{ml}$. trace element solution (Vishniac \& Santer, 1957); $0 \cdot 8 \mathrm{~g} . \mathrm{KHCO}_{3}$. The culture was forcibly aerated at $30^{\circ}$ in a cylindrical culture vessel with a basal sintered-glass air inlet. After 7-8 hr the $\mathrm{pH}$ value began to decrease, and the culture was subsequently kept approximately neutral by adding saturated $\mathrm{NaHCO}_{3}$ at intervals until all the thiosulphate was exhausted; this took $12-13 \mathrm{hr}$ in all. Aeration for a further $12 \mathrm{hr}$ provided the suspensions of starved organisms used in most experiments. The yield of bacteria was about $4 \cdot 4 \mathrm{~g}$. dry wt./mole thiosulphate oxidized.

Organisms were harvested by centrifugation, washed, and suspended in $0 \cdot 1-0 \cdot 13 \mathrm{M}$ phosphate buffer $(\mathrm{pH} \mathrm{7 \cdot 0)}$. Suspensions were diluted to give either dilute sus- 
pensions (equivalent to about $\mathbf{0 \cdot 2} \mathrm{mg}$. dry wt./ml.) or dense suspensions (equiv. about $2.5 \mathrm{mg}$. dry wt./ml.). Dense suspensions oxidized thiosulphate too rapidly for the rate to be measured accurately by manometry; accurate measurements were possible with more dilute suspensions.

Gas exchange was measured by Warburg manometry at $30^{\circ}$.

Carbon dioxide fixation was estimated by sampling Warburg flasks in which $\mathrm{KH}^{14} \mathrm{CO}_{3}$ had been added to the suspension of organisms during the experiment. At the end of the experiment, a sample of suspension was pipetted into an equal volume of ethanol containing $5 \%(\mathrm{v} / \mathrm{v})$ acetic acid. Portions of these mixtures were dried on ground-glass planchets as infinitesimally thin samples and ${ }^{14} \mathrm{C}$ counted with a scintillation counter or thin end-window G/M tube.

Sulphate was determined turbidimetrically as barium sulphate (Gleen \& Quastel, 1953) after removal of organisms by centrifugation.

Thiosulphate was determined by volumetric iodine titration.

Chromatography of sulphur compounds. This was based on the methods of Pollard (1954) and Skarżyński \& Szczepkowski (1959). With Whatman no. 4 filter paper, descending chromatograms were run at $\mathbf{2 2}^{\circ}$ with $n$-propanol + acetone + water $(5+2+3$, by vol.) containing 2 g. potassium acetate $/ 100 \mathrm{ml}$. solvent, or acetone + butanol + water $(2+2+1$, by vol. $)$ as solvents. Dried chromatograms were sprayed with $0.5 \%(\mathrm{w} / \mathrm{v}) \mathrm{AgNO}_{3}$ in ammonia solution (5 vol. aqueous ammonia solution, sp.gr. 0.88 , to 95 vol. water), and spots developed by drying and heating the paper to about $100^{\circ}$ for a few minutes to decompose the silver compounds to silver sulphide.

Chemicals. Analytical reagent grade sodium thiosulphate and sodium sulphide were used. Sodium sulphide solutions were always freshly prepared and kept in ice to minimize loss of sulphide. Dr F. H. Pollard (Bristol University) kindly gave specimens of potassium trithionate and potassium tetrathionate which were chromatographically pure.

\section{RESULTS}

Thiosulphate. This was rapidly and completely oxidized to sulphate by suspensions of washed organisms, usually at a constant rate. The $\mathrm{QO}_{\mathbf{2}}$ was commonly $1600 \mu \mathrm{l} . \mathrm{O}_{2} / \mathrm{hr} / \mathrm{mg}$. dry wt., and values up to 4000 were observed. With relatively dilute suspensions (equiv. $0 \cdot 10-0 \cdot 45 \mathrm{mg}$. dry wt. organism/flask), the rate of $\mathrm{O}_{2}$ uptake was proportional to the mass of organisms, but with more dilute suspensions (equiv. $0 \cdot 05-0 \cdot 10 \mathrm{mg}$. dry wt. organism/flask) the rate of oxidation sometimes slowed down after 40-50 min. and the thiosulphate was incompletely oxidized (compare Vishniac \& Trudinger, 1962). Up to the time at which the change in rate took place, chromatography showed that thiosulphate and trithionate were both present in the flasks; after the change to a slower rate of oxidation only trithionate was found. During thiosulphate oxidation, ${ }^{14} \mathrm{CO}_{2}$ was fixed. Fixation ceased when the thiosulphate had been completely oxidized, and there was no ${ }^{14} \mathrm{CO}_{2}$ fixation in the absence of thiosulphate (Fig. $2 a$ ). The amount of ${ }^{14} \mathrm{CO}_{2}$ fixed was proportional to the quantity of thiosulphate oxidized (Fig. 2b). Dense suspensions sometimes fixed a little more $\mathrm{CO}_{2}$ /unit thiosulphate than very dilute ones. Maximally, in these experiments, 7 mole $\mathrm{CO}_{2}$ were fixed/100 mole thiosulphate oxidized.

Sulphide. Sulphide below $\mathbf{0 . 3} \mathrm{mm}$ was oxidized rapidly by dilute suspensions, but higher concentrations were inhibitory. When an inhibitory amount of sulphide 
was added to a dilute suspension, oxidation proceeded slowly until the sulphide concentration was sufficiently lowered; the remaining sulphide was then oxidized rapidly. The organisms did not adapt to sulphide since, after the oxidation of an initial quantity of sulphide, additional sulphide was still inhibitory and the kinetics of its oxidation were identical with those of the initial quantity. When dense suspensions of organisms were used, the decrease in sulphide concentration proceeded

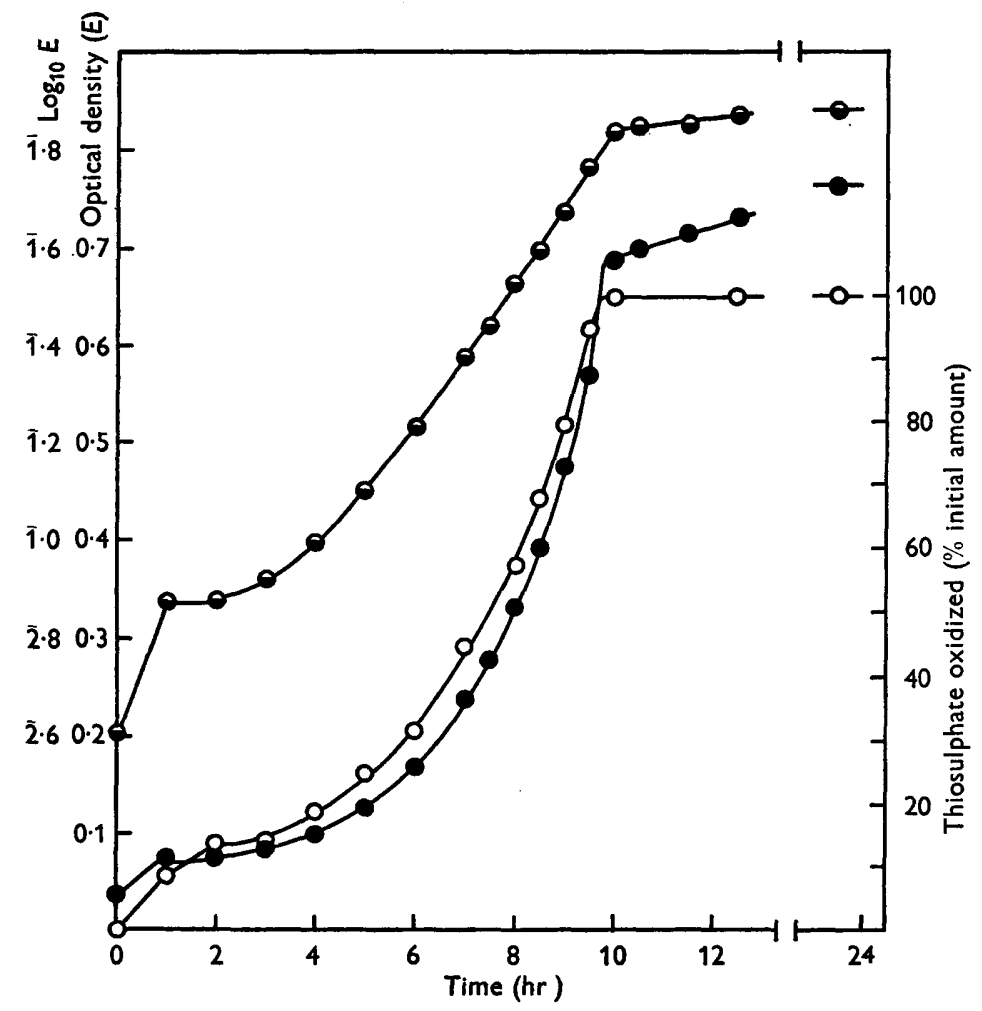

Fig. 1. Growth of Thiobacillus C. Optical density E (- - - ) and $\log _{10}$ optical density $(-\Theta-\Theta-)$ plotted against time. Note coincidence of growth and thiosulphate oxidation (-O-O- ). Temperature, $30^{\circ}$. Initially at pH 7.0.

more rapidly; $1.3 \mathrm{~mm}$-sulphide was oxidized rapidly and completely to the theoretical quantity of sulphate. Sulphide oxidation was also coupled to $\mathrm{CO}_{2}$-fixation and, with dense bacterial suspensions, ${ }^{14} \mathrm{CO}_{2}$ fixation was proportional to the quantity of sulphide oxidized (Fig. 2b). From eleven experiments, the quantity of $\mathrm{CO}_{2}$ fixed during the oxidation of one mole of sulphide was $66 \cdot 8 \pm 8 \cdot 6 \%$ of that fixed when one mole of thiosulphate was oxidized.

Polythionates. Tetrathionate and trithionate were oxidized quantitatively to sulphate, but the course of oxidation was variable, particularly with trithionate. In some experiments, the oxidation proceeded at a constant rate to completion, but, in others, the rate increased during the experiment. The oxidation of trithionate was slower in the presence of 2,4-dinitrophenol (Fig. 3) so the entry of trithionate into the cells may be an energy-requiring process. ${ }^{14} \mathrm{CO}_{2}$ was fixed during polythionate 
oxidation. With dense bacterial suspensions, ${ }^{14} \mathrm{CO}_{2}$ fixed per sulphur atom of each compound was estimated from three experiments to be: thiosulphate $100 \%$, tetrathionate $98.8 \pm 6.3 \%$, trithionate $79.5 \pm 4.6 \%$. Fixation, per molecule oxidized, was thus, thiosulphate 100 , tetrathionate 198 , trithionate 119.

Sulphite and dithionate were apparently not oxidized by Thiobacillus strain $\mathrm{c}$.
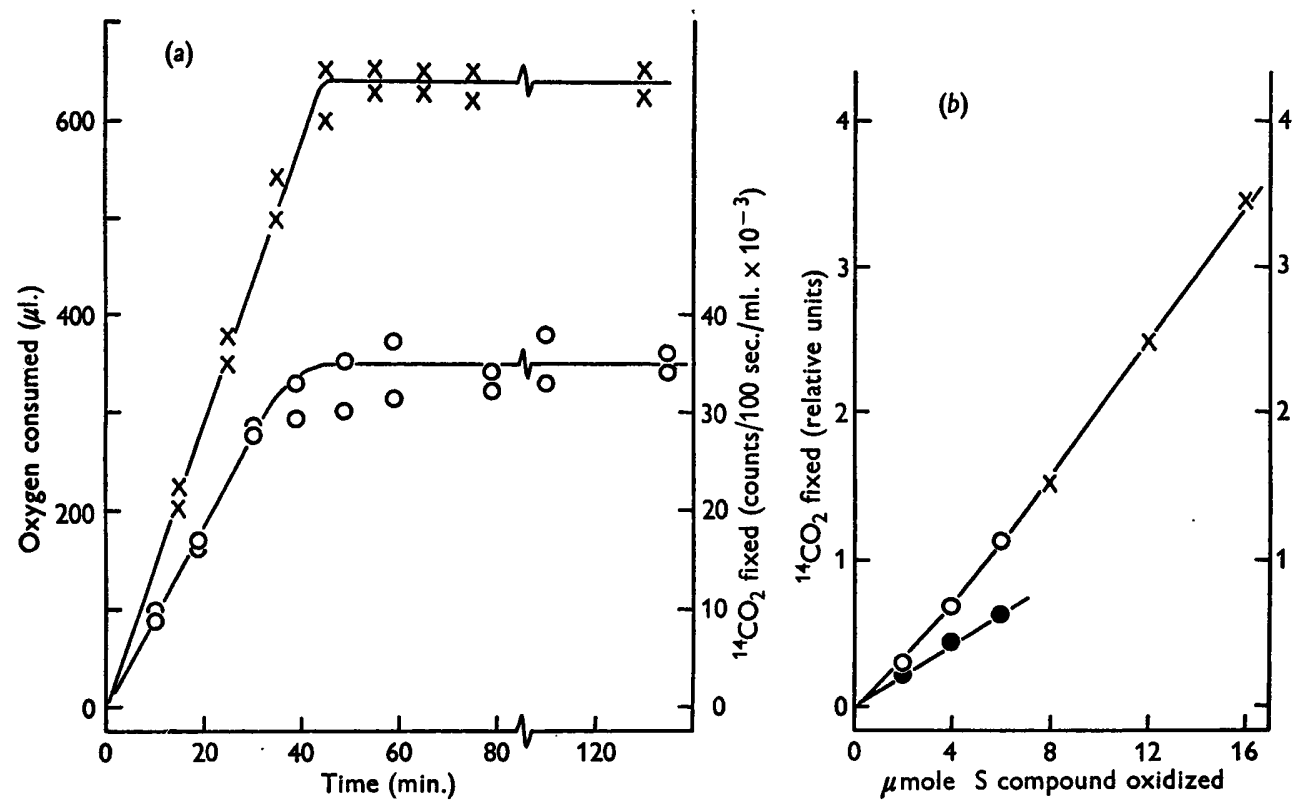

Fig. 2. (a) Oxygen uptake $(-\times-\times-)$ and ${ }^{14} \mathrm{CO}_{2}$-fixation $(-\mathrm{O}-\mathrm{O}-)$ accompanying thiosulphate oxidation. Results from replicate flasks are given. Warburg flasks contained in a final $2.0 \mathrm{ml}$ : : $1.0 \mathrm{ml}$. 0.15 $\mathrm{M}$-sodium phosphate $(\mathrm{pH} \mathrm{7.25}) ; 13 \mu$ mole $\mathrm{KH}^{14} \mathrm{CO}_{3}$ $\left(0.88 \mu \mathrm{c}{ }^{14} \mathrm{C}\right) ; 15 \mu$ mole $\mathrm{Na}_{2} \mathrm{~S}_{2} \mathrm{O}_{3}$; equiv. $0.48 \mathrm{mg}$. dry wt. Thiobacillus strain c. Sampling flasks sealed with vaccine stoppers contained five times those quantities. $\mathrm{KH}^{1{ }^{4} \mathrm{CO}_{3}}$ and $\mathrm{Na}_{2} \mathrm{~S}_{2} \mathrm{O}_{3}$ were tipped into the Warburg flasks, or injected into the sampling flasks at zero time. Samples were withdrawn at intervals from the latter, by using $1.0 \mathrm{ml}$. syringes, and the Warburg flasks sampled at the end of the experiment (135 min.). Temperature, $30^{\circ}$. Oxygen uptake for complete oxidation of added thiosulphate $=672 \mu \mathrm{l}$. $10^{6}$ counts $/ 100$ sec. $\equiv 1 \mu \mathrm{c}{ }^{14} \mathrm{C}$. In the absence of thiosulphate there was no oxygen uptake and no ${ }^{14} \mathrm{CO}_{2}$-fixation.

(b) Proportionality of ${ }^{14} \mathrm{CO}_{2}$-fixation to quantity of thiosulphate $(-\mathrm{O}-\mathrm{O}-$ and $-x-x-$ ) or sulphide (- - - ) oxidized. The results of two separate experiments with thiosulphate are shown. ${ }^{14} \mathrm{C}$-fixation was determined after added quantities of substrate had been completely oxidized. $\mathrm{pH} 7 \cdot 0$. Temperature, $30^{\circ}$.

\section{The effect of uncoupling agents on ${ }^{14} \mathrm{CO}_{2}$ fixation}

2,4-Dinitrophenol. $\mathrm{CO}_{2}$-fixation was inhibited by 2,4-dinitrophenol when any one of the above sulphur compounds was oxidized. Thiosulphate-coupled fixation was inhibited by concentrations of 2,4-dinitrophenol which stimulated or did not affect the rate of oxidation (Table 4; also Kelley \& Syrett, 1963). $\mathrm{CO}_{2}$-fixation coupled to sulphide oxidation by dense bacterial suspensions was inhibited by a similar range of 2,4-dinitrophenol concentrations (Fig. 4) and the degree of inhibition was independent of the initial sulphide concentration (Table 1). However, sulphidelinked fixation was always inhibited more than that coupled to thiosulphate oxidation, whatever the dinitrophenol concentration (Fig. 4). 
Fixation of ${ }^{14} \mathrm{CO}_{2}$, with tetrathionate as substrate, appeared to be about as sensitive to uncoupling by 2,4-dinitrophenol as that with thiosulphate as substrate (Table 2). The effect of dinitrophenol on the trithionate-linked fixation was somewhat inconsistent; this is possibly related to the variability of the time course of oxidation of this compound. Table 3 shows the results of an experiment in which trithionate was oxidized at a constant rate with'a $\mathrm{Q}_{2}$ of 180 . ${ }^{14} \mathrm{CO}_{2}$-fixation coupled to its

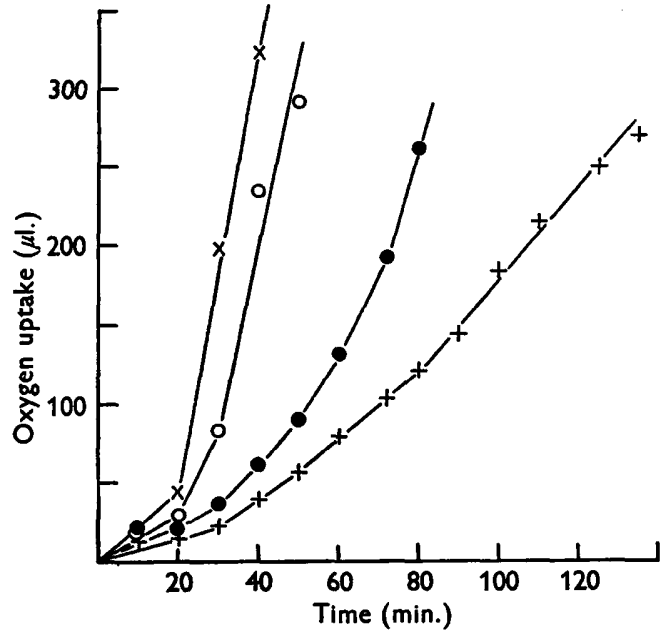

Fig. 3

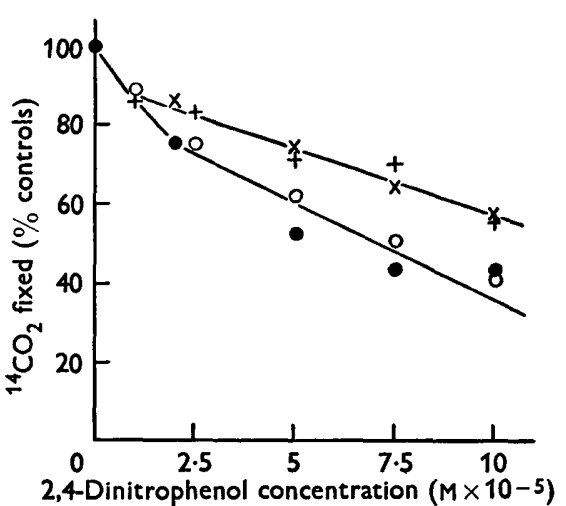

Fig. 4

Fig. 3. Inhibition of trithionate oxidation by 2,4-dinitrophenol. Equiv. 4.6 mg. dry wt. Thiobacillus strain $\mathrm{c}$ were incubated in $2.5 \mathrm{ml}$. phosphate buffer, containing 2,4-dinitrophenol, for $30 \mathrm{~min}$; $8 \mu$ mole potassium trithionate and $9 \mu$ mole $\mathrm{KHCO}_{3}$ then added (zero time on graph). Temperature $30^{\circ} ; \mathrm{pH} \mathrm{7 \cdot 0.2,4-dinitrophenol} \mathrm{concentra-}$ tions : $0(x-\times), 10^{-5} \mathrm{M}(\mathrm{O}-\mathrm{O}), 5 \times 10^{-5} \mathrm{M}(\mathrm{O}-\mathrm{O}), 10^{-4} \mathrm{M}(+-+)$.

Fig. 4. Inhibition by 2,4-dinitrophenol of ${ }^{14} \mathrm{CO}_{2}$-fixation coupled to sulphide or thiosulphate oxidation. The results of two experiments are shown. Equiv. 6.3 $\mathrm{mg}$. dry wt. Thiobacillus strain $\mathrm{c}$ in $2.5 \mathrm{ml}$. phosphate buffer $\left(\mathrm{pH} \mathrm{7.0}\right.$ ), oxidized $4 \cdot 0 \mu$ mole $\mathrm{Na}_{2} \mathrm{~S}$ or $\mathrm{Na}_{2} \mathrm{~S}_{2} \mathrm{O}_{3}$ in the presence of $9 \mu$ mole $\mathrm{KH}^{14} \mathrm{CO}_{3}\left(1.5 \mu \mathrm{c}{ }^{14} \mathrm{C}\right)$. Sulphate recovery in experiments 1 and 2 was 3.1 and $4.5 \mu$ mole from sulphide, and 8.5 and 8.2 from thiosulphate, respectively. ${ }^{14} \mathrm{CO}_{2}$-fixation, as \% of controls without 2,4-dinitrophenol, is shown for sulphide (Expt. 1,-O-O-; Expt. 2,- - - - ) and thiosulphate (Expt. 1, - + - - ; Expt. 2, - $x-x-)$.

Table 1. Relationship between quantity of sulphide oxidized and the effect of 2:4-dinitrophenol on coupled ${ }^{14} \mathrm{CO}_{2}$-fixation by Thiobacillus strain $\mathrm{C}$

The equivalent of $5.6 \mathrm{mg}$. dry wt. Thiobacillus strain $\mathrm{c}$ in $2.5 \mathrm{ml}$. phosphate buffer (pH 7.0) oxidized $\mathrm{Na}_{2} \mathrm{~S}$ in the presence of $9 \mu$ mole $\mathrm{KH}^{14} \mathrm{CO}_{3}\left(3 \mu \mathrm{c}{ }^{14} \mathrm{C}\right) .{ }^{14} \mathrm{CO}_{2}$-fixation was estimated when oxidation ceased. Temperature $30^{\circ}$.

$\begin{array}{cccc}\begin{array}{c}\text { Sulphide } \\ \text { oxidized } \\ (\mu \mathrm{mole})\end{array} & \overbrace{\text { Control }}^{{ }^{14} \mathrm{CO}_{2} \text { fixed (counts/100 sec./flask) }} & \begin{array}{c}\text { Inhibition of } \\ \mathrm{CO}_{2} \text {-fixation } \\ (\%)\end{array} \\ 1 \cdot 0 & +5 \times 10^{-5} \mathrm{M}-\mathrm{DNP} * & 46 \\ 2 \cdot 0 & 11,000 & 5,900 & 40 \\ 4 \cdot 0 & 33,450 & 20,150 & 41\end{array}$

* DNP = 2,4-dinitrophenol. 
oxidation was inhibited by dinitrophenol and, in this experiment, the inhibition was less than when thiosulphate was the substrate.

Other substituted phenols. Several aromatic compounds were tested for the ability to uncouple thiosulphate-dependent $\mathrm{CO}_{2}$-fixation (Table 4). Phenol was ineffective; $o$-nitrophenol was ineffective as an uncoupling agent, and is known to have little

Table 2. Effect of 2,4-dinitrophenol on ${ }^{14} \mathrm{CO}_{2}$-fixation coupled to thiosulphate and tetrathionate oxidation

Dense suspensions of Thiobacillus strain c (equiv. 2.5 mg. dry wt. $/ \mathrm{ml}$.) oxidized thiosulphate, or tetrathionate, completely to sulphate. ${ }^{14} \mathrm{CO}_{2}$-fixation and sulphate production were then measured. Sulphate recoveries in experiments 3 and 4 , as $\%$ of expected amounts, were $107 \cdot 5$ and 115 for thiosulphate, and 109 and 108 for tetrathionate. Oxygen consumption always approximated to the theoretical values. Temperature $30^{\circ}$. pH 7.0.

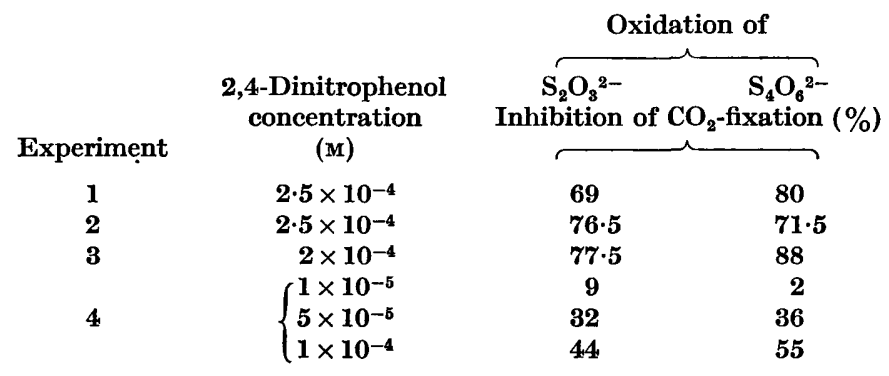

Table 3. Fixation of ${ }^{14} \mathrm{CO}_{2}$ during thiosulphate or trithionate oxidation by Thiobacillus sp. strain $c$ and the effect of 2,4-dinitrophenol

Thiobacillus c equiv. $6 \cdot 3 \mathrm{mg}$. dry wt. oxidized $\mathrm{Na}_{2} \mathrm{~S}_{2} \mathrm{O}_{3}(9 \mu$ mole $)$ or $\mathrm{K}_{2} \mathrm{~S}_{3} \mathrm{O}_{6}(6 \mu$ mole $)$ in the presence of $\mathrm{KH}^{14} \mathrm{CO}_{3}$. The 2,4-dinitrophenol concentration was $5 \times 10^{-5} \mathrm{M} ; \mathrm{pH}$ $\mathbf{7 \cdot 0}$; temperature, $30^{\circ}$.

\begin{tabular}{|c|c|c|c|}
\hline Treatment & $\begin{array}{c}{ }^{14} \mathrm{CO}_{2} \text { fixed } \\
\text { (counts/100 sec.) }\end{array}$ & $\begin{array}{l}{ }^{14} \mathrm{CO}_{2} \text { fixed } \\
\text { (\%/ } / \mu \text { atom } \\
\text { sulphur) }\end{array}$ & $\begin{array}{c}\text { Inhibition } \\
\text { of fixation } \\
\text { by } 2,4- \\
\text { dinitrophenol } \\
(\%)\end{array}$ \\
\hline $\begin{array}{l}\mathrm{Na}_{2} \mathrm{~S}_{2} \mathrm{O}_{3} \\
\mathrm{~K}_{2} \mathrm{~S}_{3} \mathrm{O}_{6} \\
\mathrm{Na}_{2} \mathrm{~S}_{2} \mathrm{O}_{3}+2,4 \text {-dinitrophenol } \\
\mathrm{K}_{2} \mathrm{~S}_{3} \mathrm{O}_{6}+2,4 \text {-dinitrophenol }\end{array}$ & $\begin{array}{l}7 \cdot 12 \times 10^{4} \\
5 \cdot 10 \times 10^{4} \\
4 \cdot 08 \times 10^{4} \\
3 \cdot 66 \times 10^{4}\end{array}$ & $\begin{array}{r}100 \\
72 \\
100 \\
89 \cdot 5\end{array}$ & $\begin{array}{l}- \\
\overline{42 \cdot 5} \\
28 \cdot 5\end{array}$ \\
\hline
\end{tabular}

effect on oxidative phosphorylation in other systems (Cross et al. 1949; Clowes et al. 1950). Picric acid inhibited fixation at high concentrations but its effect was probably complex; in other systems it is a poor uncoupling agent. Dichloro- and $p$-nitrophenol are well established as inhibitors of oxidative phosphorylation (Hackett, 1960; Clowes et al. 1950) and effectively uncoupled $\mathrm{CO}_{2}$-fixation by our Thiobacillus. Low concentrations of 2,6-dichloro-4-nitrophenol probably have a similar effect (Krahl \& Clowes, 1936) but high concentrations inhibit the oxidation of thiosulphate. 2,4-Dinitrophenol (2 mM) depressed the rate of oxygen uptake by more than $80 \%$.

Arsenate. The effect of a range of arsenate concentrations on ${ }^{14} \mathrm{CO}_{2}$-fixation by 
dense bacterial suspensions oxidizing thiosulphate or sulphide was measured (Table 5); in these experiments, the phosphate concentration remained constant. ${ }^{14} \mathrm{CO}_{2}$-fixation coupled to oxidation of thiosulphate or sulphide was inhibited by arsenate: phosphate ratios of the order of unity, but the fixation coupled to sulphide

Table 4. Effect of substituted aromatic compounds on thiosulphate-linked ${ }^{14} \mathrm{CO}_{2}$-fixation by Thiohacillus strain $\mathrm{C}$

\begin{tabular}{|c|c|c|c|}
\hline Compound & Concentration (M) & $\begin{array}{l}\text { Inhibition of } \\
{ }^{14} \mathrm{CO}_{2} \text {-fixation } \\
\text { (\% of control) }\end{array}$ & $\begin{array}{c}\text { Initial } \\
\text { oxidation rate } \\
\text { ( } \% \text { difference } \\
\text { from controls) }\end{array}$ \\
\hline \multicolumn{4}{|l|}{ Experiment 1} \\
\hline $\left.\begin{array}{l}\text { Phenol } \\
o \text {-Nitrophenol } \\
p \text {-Nitrophenol } \\
2,4 \text {-Dinitrophenol } \\
\text { 2,4,6-Trinitrophenol } \\
p \text {-Nitroaniline } \\
p \text {-Nitroanisole } \\
p \text {-Nitrobenzyl alcohol }\end{array}\right\}$ & $2 \times 10^{-4}$ & $\left\{\begin{array}{l}0 \\
8 \cdot 5 \\
34 \\
48 \cdot 5 \\
10 \cdot 5 \\
14 \\
0 \\
1\end{array}\right.$ & $\begin{array}{c}\dot{ } \\
\dot{1} \\
\dot{15} \\
\dot{\cdot} \\
\dot{.}\end{array}$ \\
\hline o-Nitrophenol & $\begin{array}{r}10^{-4} \\
5 \times 10^{-4}\end{array}$ & $\begin{array}{l}14 \cdot 5 \\
16\end{array}$ & $\begin{array}{l}-10 \\
-13\end{array}$ \\
\hline$p$-Nitrophenol & $\begin{array}{r}10^{-5} \\
5 \times 10^{-5} \\
10^{-4} \\
5 \times 10^{-4}\end{array}$ & $\begin{array}{r}0 \\
4 \\
12 \\
91\end{array}$ & $\begin{array}{c}\dot{.} \\
+20\end{array}$ \\
\hline \multicolumn{4}{|l|}{ Experiment 2} \\
\hline 2,4-Dinitrophenol & $\begin{array}{r}10^{-5} \\
5 \times 10^{-5} \\
10^{-4} \\
5 \times 10^{-4}\end{array}$ & $\begin{array}{l}3 \cdot 5 \\
14 \\
49 \cdot 5 \\
74 \cdot 5\end{array}$ & $\dot{\dot{.}}$ \\
\hline 2,4,6-Trinitrophenol & $\begin{array}{r}10^{-4} \\
5 \times 10^{-4}\end{array}$ & $\begin{array}{r}7 \cdot 5 \\
38 \cdot 5\end{array}$ & $\begin{array}{l}-7 \\
-15\end{array}$ \\
\hline 2,4-Dichlorophenol & $\begin{array}{r}10^{-5} \\
5 \times 10^{-5} \\
10^{-4} \\
5 \times 10^{-4}\end{array}$ & $\begin{array}{c}0 \\
12 \cdot 5 \\
47 \\
100\end{array}$ & $\begin{array}{c}\dot{.} \\
-21 \\
-48\end{array}$ \\
\hline 2,6-Dichloro-4-nitrophenol & $\begin{array}{r}10^{-5} \\
5 \times 10^{-5} \\
10^{-4} \\
5 \times 10^{-4}\end{array}$ & $\begin{array}{r}0 \\
27 \\
\mathbf{3 3} \\
\mathbf{9 9}\end{array}$ & $\begin{array}{c}\dot{\cdot} \\
-50 *\end{array}$ \\
\hline
\end{tabular}

* $5 \times 10^{-4} \mathrm{M}$ 2,6-dichloro-4-nitrophenol blocked the oxidation after only $3.8 \mu$ mole of the theoretical $20 \mu$ mole of oxygen had been consumed.

oxidation was the more sensitive to the inhibitor. The rate of thiosulphate oxidation by dilute bacterial suspensions was unaffected by these arsenate:phosphate ratios.

Azide. Sodium azide inhibited both thiosulphate oxidation and ${ }^{14} \mathrm{CO}_{2}$ fixation. Both reactions were inhibited by $50 \%$ by $10^{-4} \mathrm{M}$-azide and completely inhibited by $5 \times 10^{-4}$ M. Azide, therefore, has no specific uncoupling effect on this system. Iwatsuka, Kuno \& Maruyama (1962) obtained a similar result with Thiobacillus thiooxidans. 
Table 5. Inhibition of ${ }^{14} \mathrm{CO}_{2}$-fixation in Thiobacillus strain o by arsenate Dense suspensions of Thiobacillus strain $\mathrm{c}$ in $0.003 \mathrm{M}$-phosphate buffer (pH 7 ) were
added to phosphate + arsenate buffer mixtures in Warburg flasks and incubated at $30^{\circ}$,
pH $7 \cdot 0$, for $30-40$ min. $\mathrm{KH}^{14} \mathrm{CO}_{3}$ and $\mathrm{Na}_{2} \mathrm{~S}$ or $\mathrm{Na}_{2} \mathrm{~S}_{2} \mathrm{O}_{3}$ were added. ${ }^{14} \mathrm{CO}_{2}$-fixation was
measured when oxidation was complete. The final phosphate concentration was $0 \cdot 05 \mathrm{M}$
in each experiment.

\begin{tabular}{|c|c|c|c|}
\hline $\begin{array}{c}\text { Arsenate } \\
\text { concentration } \\
\text { (M) }\end{array}$ & $\begin{array}{l}\text { Arsenate: phosphate } \\
\text { ratio }\end{array}$ & $\overbrace{}^{{ }^{\mathrm{S}_{2} \mathrm{O}_{8}{ }^{2-}} \mathrm{CO}_{2} \text { fixed }}$ & $\begin{array}{r}\mathbf{S}^{2-} \\
(\%) \\
\end{array}$ \\
\hline \multicolumn{4}{|l|}{ Experiment 1} \\
\hline $\begin{array}{l}0 \\
0 \cdot 02 \\
0 \cdot 05\end{array}$ & $\begin{array}{l}0 \\
0 \cdot 4 \\
1 \cdot 0\end{array}$ & $\begin{array}{l}100 \\
115 \\
102\end{array}$ & $\begin{array}{r}100 \\
77 \\
61\end{array}$ \\
\hline \multicolumn{4}{|c|}{ Experiment 2} \\
\hline $\begin{array}{l}0 \\
0 \cdot 001 \\
0.01 \\
0 \cdot 05 \\
0 \cdot 1\end{array}$ & $\begin{array}{l}0 \\
0 \cdot 02 \\
0 \cdot 2 \\
1 \cdot 0 \\
2 \cdot 0\end{array}$ & $\begin{array}{r}100 \\
105 \\
80 \\
81 \\
80\end{array}$ & $\begin{array}{r}100 \\
96 \\
89 \\
33 \\
22\end{array}$ \\
\hline \multicolumn{4}{|l|}{ Experiment 3} \\
\hline $\begin{array}{l}0 \\
0 \cdot 01 \\
0 \cdot 025 \\
0 \cdot 05 \\
0 \cdot 1\end{array}$ & $\begin{array}{l}0 \\
0 \cdot 2 \\
0 \cdot 5 \\
1 \cdot 0 \\
2 \cdot 0\end{array}$ & $\begin{array}{r}100 \\
112 \\
102 \\
72 \\
21\end{array}$ & $\begin{array}{r}100 \\
87 \\
82 \\
56 \\
17\end{array}$ \\
\hline
\end{tabular}

\section{DISCUSSION}

$\mathrm{CO}_{2}$-fixation in Thiobacillus takes place chiefly by the Calvin cycle (Aubert et al. 1957) and presumably these reactions require a supply of reduced NAD or NADP and ATP (Racker, 1955). Since, in our experiments, $\mathrm{CO}_{2}$-fixation is inhibited by low concentrations of 2,4-dinitrophenol, which uncouples phosphorylation in other systems, one can assume that the amount of $\mathrm{CO}_{2}$-fixation indicates the quantity of high-energy phosphate available to the organisms. Taking the value with thiosulphate as substrate as $100, \mathrm{CO}_{2}$-fixation/mole substrate oxidized was 119 units with trithionate, 198 with tetrathionate and 67 with sulphide. Since, however, these compounds contain different numbers of sulphur atoms, a better comparison is $\mathrm{CO}_{2}$-fixation/sulphur atom oxidized. The figures then are, with thiosulphate as 100 , trithionate 80, tetrathionate 99 and sulphide 134 .

The complete oxidation to sulphate of one molecule of sulphide or thiosulphate requires two molecules of oxygen. Nevertheless, only about two-thirds as much $\mathrm{CO}_{2}$-fixation is coupled to the oxidation of sulphide. If the amount of $\mathrm{CO}_{2}$ fixed does indicate the quantity of high-energy phosphate made available during oxidation, this difference suggests that the oxidation of a molecule of thiosulphate is linked to more phosphorylating steps than that of one of sulphide. An additional phosphorylation would occur during thiosulphate oxidation if the substrate-level phosphorylation studied by Peck (1962) in cell-free extracts also takes place in intact organisms.

The inhibition of $\mathrm{CO}_{2}$-fixation by 2,4-dinitrophenol, and other phenolic compounds 
which are known to uncouple oxidative phosphorylations in mitochondrial systems, indicates that oxidative phosphorylation plays a part in the coupling between substrate oxidation and $\mathrm{CO}_{2}$-fixation in Thiobacillus. However, $\mathrm{CO}_{2}$-fixation coupled to sulphide oxidation is always more sensitive to 2,4-dinitrophenol inhibition than is the $\mathrm{CO}_{2}$-fixation coupled to thiosulphate oxidation. Such a difference in sensitivity would be expected if the substrate phosphorylation, studied by Peck, is relatively more important in supplying energy for $\mathrm{CO}_{2}$-fixation during the oxidation of thiosulphate than it is when sulphide is oxidized. This view is supported by the observation that the ATP content of intact Thiobacillus organisms increases rapidly after the addition of thiosulphate or sulphide(Kelly \& Syrett, unpublished); but, whereas, when thiosulphate is added, this increase is unaffected by 2,4-dinitrophenol, it is strongly inhibited when sulphide is the substrate. If the only phosphorylations coupled to sulphide oxidation are oxidative ones, sensitive to 2,4-dinitrophenol, then our data indicate that two-thirds of the phosphorylations coupled to thiosulphate oxidation are of this type and one-third are unaffected by 2,4-dinitrophenol (Kelly \& Syrett, 1963). As yet, the pathway of sulphide oxidation is uncertain and the possibility of some substrate phosphorylation during sulphide oxidation cannot be excluded.

Arsenate can replace phosphate in many enzyme reactions and, with it, ADPsulphurylase catalyses the arsenolysis of adenosine-5' -phosphosulphate (Robbins \& Lipmann, 1958). Both this enzyme and adenosine phosphosulphate are reactants in the phosphorylation system studied by Peck \& Fisher (1962) and, in their cell-free extracts, arsenate could replace for phosphate in catalysing the oxidation of thiosulphate to sulphate. However, when phosphate and arsenate were both present, in equimolar quantities, phosphate esterification was unaffected by arsenate. Thus arsenate competes poorly with phosphate in the reaction with adenosine phosphosulphate. On the other hand, an arsenate:phosphate ratio of unity uncouples oxidative phosphorylation in a mitochondrial system (Crane \& Lipmann, 1953). Our results with whole organisms of Thiobacillus show that arsenate resembles 2,4-dinitrophenol in that a given concentration inhibits ${ }^{14} \mathrm{CO}_{2}$-fixation more when sulphide is the substrate than with thiosulphate. The difference in sensitivity again suggests that thiosulphate oxidation is linked to a type of phosphorylation which is relatively less important in the oxidation of sulphide.

When tetrathionate is added, $\mathrm{CO}_{2}$-fixation/sulphur atom oxidized is very similar to fixation with thiosulphate as substrate and the sensitivity to 2,4-dinitrophenol inhibition is much the same. Such similarity is to be expected if the first step in the metabolism of a molecule of tetrathionate is its conversion to two molecules of thiosulphate (Peck \& Fisher, 1962). The present results with trithionate suggest less $\mathrm{CO}_{2}$-fixation/sulphur atom oxidized than with the other substrates and a lower sensitivity to 2,4-dinitrophenol. It is attractive to think that the trithionate ion, $\mathrm{S}_{3} \mathrm{O}_{6}{ }^{2-}$, might be reduced to two sulphite ions and one of sulphide. If this sulphite were then oxidized with a coupled substrate phosphorylation as suggested by Peck, phosphorylations insensitive to 2,4-dinitrophenol might be quantitatively more important in the oxidation of trithionate in Thiobacillus than in the oxidation of thiosulphate, $\mathrm{S}_{2} \mathrm{O}_{3}{ }^{2-}$, where only one sulphite ion, together with one of sulphide, is formed on reduction. 
We thank Dr F.H.Pollard of the Department of Physical and Inorganic Chemistry, Bristol University, for gifts of pure potassium trithionate and tetrathionate. A research grant from the Department of Scientific and Industrial Research is gratefully acknowledged.

\section{REFERENCES}

Aubert, J-P., Milhaud, G. \& Millet, J. (1957). L'assimilation de l'anhydride carbonique par les bactéries chimioautotrophes. Annls. Inst. Pasteur, Paris 92, 515.

Clowes, G. H. A., Keltch, A. K., Strittmatter, C. F. \& Walters, C. P. (1950). Action of nitro- and halophenols upon oxygen consumption and phosphorylation by a cell free particulate system from Arbacia eggs. J. gen. Physiol. 33, 555.

Crane, R. K. \& LipmanN, F. (1953). The effect of arsenate on aerobic phosphorylation. J. biol. Chem. 201, 235.

Cross, R. J., Taggart, J. V., Covo, G. A. \& Green, D. E. (1949). Studies on the cyclophorase system. VI. The coupling between oxidation and phosphorylation. J. biol. Chem. 177, 655.

Gleen, H. \& Quastel, J. H. (1953). Sulphur metabolism in soil. Appl. Microbiol. 1, 70.

HaCkett, D. P. (1960). Respiratory inhibitors. Encyclopaedia of Plant Physiology (Ed. W. Ruhland), 12, part 2, 23.

Iwatsuka, H., Kuno, M. \& Maruyama, M. (1962). Studies on the metabolism of a sulphuroxidizing bacterium. II. The system of $\mathrm{CO}_{2}$-fixation in Thiobacillus thiooxidans. Plant Cell Physiol. 3, 157.

Jones, G. L. \& HAPPoLd, F. C. (1961). The occurrence of polythionates as intermediates in the metabolism of thiosulphate by the thiobacilli. J. gen. Microbiol. 26, 361 .

Kelly, D. P. \& Syrett, P. J. (1963). Effect of 2:4-dinitrophenol on carbon dioxide fixation by a Thiobacillus. Nature, Lond. 197, 1087.

Krahl, M. E. \& Clowes, G. H. A. (1936). Studies on cell metabolism and cell division. J. gen. Physiol. 20, 173.

Milmaud, G., Aubert, J-P. \& Mrluet, J. (1957). Synthèse de l'adenosine-5' -triphosphate couplée à l'oxydation du thiosulfate par la bactérie chimioautotrophe Thiobacillus denitrificans. C.R. Acad. Sci., Paris, 244, 1289.

Peck, H. D., Jr. (1960). Adenosine-5'-phosphosulfate as an intermediate in the oxidation of thiosulfate by Thiobacillus thioparus. Proc. nat. Acad. Sci., Wash. 46, 1053.

PeCr, H. D., JR. (1962). Comparative metabolism of inorganic sulfur compounds in microorganisms. Bact. Rev. 26, 67.

PeCK, H. D., Jr. \& Fisher, E., Jr. (1962). The oxidation of thiosulfate and phosphorylation in extracts of Thiobacillus thioparus. J. biol. Chem. 237, 190.

Pollard, F. H. (1954). Inorganic chromatography. Bri. med. Bull. 10, 187.

RACKER, E. (1955). Synthesis of carbohydrates from carbon dioxide and hydrogen in a cell free system. Nature, Lond. 175, 249.

Robbins, P. W. \& Lipmann, F. (1958). Separation of the two enzymatic phases in active sulfate synthesis. J. biol. Chem. 233, 681 .

SkarżyŃskI, B. \& SzCzepkowski, T. W. (1959). Oxidation of thiosulphate by Thiobacillus thioparus. Nature, Lond. 183, 1413.

Suzurr, I. \& Werkman, C. H. (1958). Chemoautotrophic carbon dioxide fixation by extracts of Thiobacillus thiooxidans. I. Formation of oxalacetic acid. Archs. Biochem. 76, 103.

Trudinger, P. A. (1956). Fixation of carbon dioxide by extracts of the strict autotroph Thiobacillus denitrificans. Biochem. J. 64, 274.

Trudinger, P. A. (1959). The initial products of thiosulphate oxidation by Thiobacillus $X$. Biochim. biophys. Acta, 31, 270.

Vishniac, W. (1952). The metabolism of Thiobacillus thioparus. I. The oxidation of thiosulfate. J. Bact. 64, 363.

Vishniac, W. \& SANTER, M. (1957). The Thiobacilli. Bact. Rev. 21, 195.

Vishniac, W. \& Trudinger, P. A. (1962). Carbon dioxide fixation and substrate oxidation in the chemoautotrophic sulfur and hydrogen bacteria. Bact. Rev. 26, 168. 